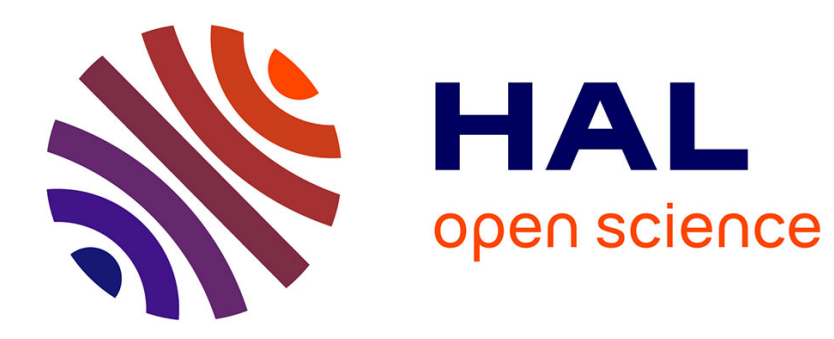

\title{
Why do Russian firms invest abroad? A firm level analysis
}

Amar Iqbal Anwar, Mazhar Mughal

\section{To cite this version:}

Amar Iqbal Anwar, Mazhar Mughal. Why do Russian firms invest abroad? A firm level analysis. 2014. hal-01885147

\section{HAL Id: hal-01885147 \\ https://hal-univ-pau.archives-ouvertes.fr/hal-01885147}

Preprint submitted on 24 Sep 2020

HAL is a multi-disciplinary open access archive for the deposit and dissemination of scientific research documents, whether they are published or not. The documents may come from teaching and research institutions in France or abroad, or from public or private research centers.
L'archive ouverte pluridisciplinaire HAL, est destinée au dépôt et à la diffusion de documents scientifiques de niveau recherche, publiés ou non, émanant des établissements d'enseignement et de recherche français ou étrangers, des laboratoires publics ou privés. 


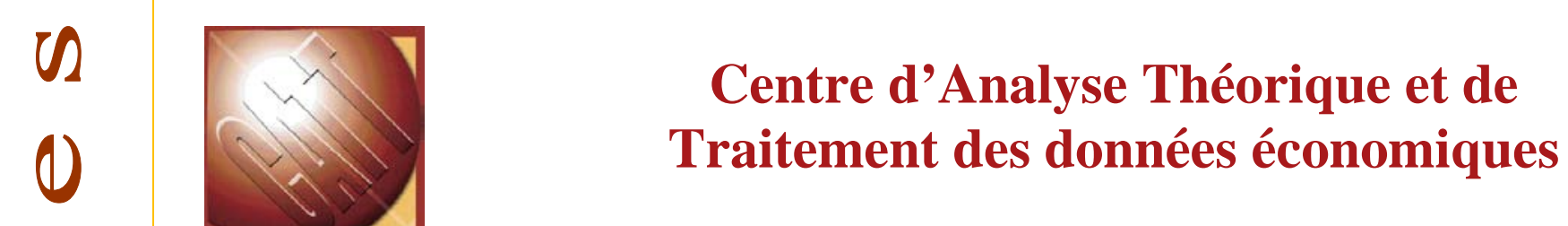

0

CATT WP No. 1

September 2014

WHY DO RUSSIAN FIRMS INVEST ABROAD? A FIRM LEVEL ANALYSIS

Tél. (33) 559408001

Amar Iqbal ANWAR Mazhar Yasin MUGHAL 


\title{
Why do Russian firms invest abroad? A firm level analysis
}

\author{
Amar I. Anwar * and Mazhar Y. Mughal ${ }^{* *}$
}

\begin{abstract}
This study examines the motives for Russian outward foreign direct investments (OFDI) around the world. Using firm-level data for Russian firms, home and host country economic, geographical, cultural and institutional drivers of Russian OFDI are analyzed. Findings show that Russian OFDI seems to be motivated by both the push and the pull factors. Results suggest market-seeking to be the main motive behind Russian outward foreign direct investments, followed by resource and technology acquisition, while efficiency-seeking does not appear to be a major objective. Compared with the pre-crisis period, Russian firms have been seeking more foreign investments since 2008. The study helps better understand the economic, geographical, cultural and institutional factors that Russian transnational corporations consider while planning investments abroad.
\end{abstract}

Key words: Outward Foreign Direct Investment; 2008 financial crisis; Russia.

JEL codes: F23; G01; O53

*Amar I. Anwar

Shannon School of Business, Cape Breton University

Sydney, Nova Scotia, Canada, B1P 6L2

Email: $\underline{\text { amar_anwar@cbu.ca }}$

** Mazhar Y. Mughal

Pau Business School, France

Mazhar.mughal@esc-pau.fr

Corresponding author: Amar I. Anwar (Email: amar_anwar@cbu.ca) 


\section{Introduction}

In today's globalizing economy, the role of foreign direct investments is being increasingly recognized. Although Outward Foreign Direct Investments (OFDI) from the developed countries have been examined in the business literature for decades, there is still room for further analysis of the OFDI from emerging and developing economies. OFDI are said to help investing firms increase their revenues and profits, acquire strategic assets and gain access to raw materials, and improve market reach (UNCTAD, 2007). They have become an indispensible strategic tool for acquiring access to resources abroad such as raw materials, energy, skilled labour, technology and know-how (De Beule and Den Bulcke, 2012). When investing abroad, which country factors do emerging markets transnational corporations (TNCs) consider? What are the motives behind these investment decisions? Whether the home or the host-country specific factors dominate? Did the recent global financial crisis have any impact on the motivation behind the foreign forays by these new players on the international investor scene? We study these questions by examining annual outbound investment activities of Russian corporations during the 1999 - 2012 period.

\section{Insert fig. 1 here}

As shown in figure 1, Russian Federation is the largest outward investor among emerging economies with OFDI in 2012 flows equalling 2.6\% of the national output, surpassing People's Republic of China (henceforth China), Brazil and India (UNCTAD, 2013). Russian OFDI flows rose from an average of $\$ 14.3$ billion during the pre-crisis period (1999 - 2007) to a post crisis (2008 - 2012) level of $\$ 53.89$ billion, a 3.76 fold increase UNCTAD 2013). In comparison, average OFDI flows from other BRIC countries (Brazil, China, India) in the post-crisis period were $0.63,7.6$ and 3.17 times the pre-crisis levels. This is despite the fact that Russia was initially the worst hit of all G-20 countries during the global financial crisis, with GDP falling by a hefty 7.9\% year-on- year in 2009 (WDI, 2013). In comparison, China and India's GDP rose by $9.2 \%$ and $8.5 \%$ respectively while Brazil's fell by $0.3 \%$ (WDI, 2013).

In this study, we analyze various home and host country economic, geographical, cultural and institutional factors that determine Russian firms' choice of investment destinations. In doing so, we estimate the strength of various investment motives and examine the effect of the 2008 
global financial crisis on their investment behaviour. We find that market-seeking stands out as an important motive of Russian firms' foreign investments followed by natural resources and technology acquisition. Both push (e.g. home country economic and institutional environment) and pull (e.g. host country market, natural resources and technology) seem to drive Russian FDI outflows. Moreover, the 2008 global financial crisis has an amplifying effect on Russian outward investments, ceteris paribus.

The remainder of the study is organized as follows. Next section briefly overviews Russian firms' international investment profile. Section 3 briefly gives the study's theoretical background. Section 4 introduces the dataset and presents the empirical methodology. Key findings are presented and discussed in Section 5, followed by the study's main conclusions in Section 6.

\section{Outward foreign investments by Russian firms}

Russia went through a severe economic crisis in 1998, as the economy shrank by $5.3 \%$ and the national currency fell sharply. Economic conditions have greatly improved since, partly as a result of rising prices of oil and gas and Russia's rising mineral production. Incomes have risen and investment has grown. Several energy, banking, industrial and retail conglomerates have emerged, and Russia now boasts seven corporations in the Global 500 list (Table 1). Two of these Russian giants, Gazprom and Lukoil, rank among the World's 50 biggest firms.

\section{Insert table 1 here}

Since the mid-2000s, Russian firms have begun increasingly internationalizing. Several Russian corporations (particularly those involved in the extraction of natural resources) are cash rich and have sought to acquire foreign assets. This strategic buying spree often has Russian government's tacit support. Both major Russian state owned enterprises and private corporations have made foreign investments, usually seeking downstream markets (Kalotay, 2010). Russian firms such as Lukoil, Gazprom, Inter RAO, Novolipetsk Steel etc. have used their access to Russia's vast natural resource endowments to build a strong international presence in refining, rolling, transportation and distribution activities (Skolkovo Research, 2009; UNCTAD, 2005). Table 2 shows top outward investing Russian corporations by volume of investments. 


\section{Insert table 2 here}

\section{Insert figure 2 here}

Most of the Russian investment projects abroad have been mergers and acquisitions (M\&A) in the financial, consumer products, natural resources and energy sectors (figure 2), with investments in the primary sector accounting for over half of the total amount of OFDI.

Russian OFDI is mainly concentrated in the OECD countries as well as East European and former Soviet Republics (Table 3). Initially, former Soviet Republics were the Russian firms' major investment destinations (Table 3 Panel A. These investments mostly sought access to natural resources (for example Lukoil's operations in Azerbaijan or the Russian steel maker Mechel's investments in Kazakhstan), or to capture the countries consumer markets (for example Mobile TeleSystems' investments in Ukraine's and most other former Soviet Republics' telecommunication networks, or electricity producer and supplier RAO UES's operations in Armenia, Georgia, Moldova and Ukraine). However, preference for these Commonwealth of Independent States (CIS) countries has gradually waned. Unlike the pre2008 financial crisis period when ten of these states figured in Russian firms' top 25 investment destinations, only five featured in the post-crisis period (Table 3 Panel B), namely Belarus, Ukraine, Kazakhstan, Estonia and Armenia. East European countries in particular are attracting higher investment flows from Russia. Among other BRIC countries, only China features in top 25 Russian investment destinations. Western Europe and North America still remain major recipients of the Russian TNC. Nonetheless, investments in countries such as Cyprus and Luxembourg and even the Netherlands and the United Kingdom are sometimes used for round tripping or re-investment in the domestic economy to benefit from investment incentives granted to foreign investors (Kuznetsov, 2010, Filippov, 2008). This last use of outbound investments by Russian firms means that some of Russian OFDI flows relate to capital flight, and therefore can only be considered an approximation of Russian OFDI (Filippov, 2011).

\section{Insert Table 3 here:}

Most Russian TNCs are large exporters and consequently rely on exports receipts to finance their foreign investments (Imemo, 2009). For this reason, Russian TNCs were badly hit at the onset of the 2008 financial crisis as prices for their exports commodities fell sharply. For 
instance, prices of oil, nickel and steel plunged by 54\%, 63\% and 20\% respectively (Kalotay, 2010). Corporate debt of Russian firms rose to close to $\$ 110$ billion and firms like Rusal, Norilsk Nickel, TMK and Sistema faced financial difficulties due to high debt repayments (Andreff, 2013). Several major corporations received financial support from the state-owned Bank for Development and Foreign Economic Affairs VEB (Filippov, 2011), and Russian government's role in the country's corporate sector increased (Filippov, 2011).

Although Russian OFDI stock fell in 2008, foreign investments (especially those by stateowned Russian corporations) have rebounded and Russian OFDI stock in 2012 is $12 \%$ larger as compared to the one before the outbreak of the 2008 financial crisis.

\section{Theoretical background}

According to Dunning's Eclectic paradigm, firms possess comparative advantage over their competitors based on ownership of unique and complementary assets which they exploit to gain locational advantage (Dunning 1979, 1988). The paradigm combines elements from the theories of transaction cost (internalization) and market power. Firms choose to internationalize by investing abroad for four major reasons (Dunning, 1993): seeking foreign markets, improving efficiency, gaining access to resources, or acquiring assets. Market seeking outward investments help the firm take advantage of the host economy's market size by producing products for the local market. Increasing the firm's market share allows the firm to realize economies of scale and scope, and thus improve its efficiency. Efficiency seeking investments benefit from differences between home and host country costs to lower production and transaction costs and increase production. Resource seeking investments provide the firm access to the host country's abundant tangible and intangible resources. These resources can be natural (e.g. raw materials, minerals) or human (professionals, skilled and unskilled manpower).

These three investment motives can be called asset exploiting motives (Makino et al. 2002). The three motives essentially involve transferring the firm's proprietary assets from the home to the host country and result from the firm's desire to improve short run returns (March 1991). In contrast, asset augmenting or asset seeking investments seek to enhance the firm's long term non-price competitiveness by acquiring strategic assets such as new technology, delivery and distribution infrastructure, brand names, patents and licenses. Such outward investments improve the long term revenue generation potential of emerging economies 
TNCs and help them compete with multinationals from the developed countries by allowing them access to technology and technical and managerial knowhow (UNCTAD 2006).

In essence, the drivers of FDI outflows are due to differences in availability of resources between home and host country and can be classified as either push and pull factors (Anwar, 2009; Kumar, 1982; UNCTAD, 2005). These differences can be either country or firmspecific. Push factors pertain to saturated domestic market, high labor costs or resource unavailability, while pull factors consist of host country locational advantages (Anwar and Mughal 2013).

As described in the previous section, Russian TNCs have generally invested in the developed countries of Western Europe and North America as well as in the neighboring CIS countries, and both market seeking and efficiency seeking motives have been present in these investments. However, in recent years, Russian TNCs have increasingly looked for access to natural resources and strategic assets. This raises the question as to which of the four investment motives have been most important for Russian OFDI. As well, whether Russian FDI outflows are motivated mainly by the push or the pull factors? In the following, we investigate these questions empirically.

\section{Data and methodology}

\subsection{Data description}

In this study, we analyze various investment motives of Russian TNCs by employing detailed S\&P Capital database. S\&P Capital provides worldwide data on mergers and acquisitions (M\&A) along with equity participation, state ownership and firms' ownership advantages like firm's age, number of employees, R\&D expenditures and sales. The database provides total number of M\&A deals and the resulting amount of OFDI starting from 1999. Although data on Russian outward investments are available for over 100 countries, we restrict our dataset to Russian TNCs' top 55 investment destinations, disregarding negligible and infrequent investment destinations. Those M\&A deals which are in progress or cancelled are excluded from the data.

We include a host of variables pertaining to the economic, institutional and geographical situation of both the home and the host countries to represent the push and pull factors. OFDI 
are influenced by push factors such as home country's economic activity and inflation as well as pull factors such as the host country market size, inflation, number of patents issued and natural resource exports. Similarly, exports to a host country can affect the volume of OFDI to that country. Geographical proximity and cultural affinity with host country can also facilitate foreign investments. Russian investments have traditionally targeted countries of the former USSR and the communist bloc, many of which share linguistic, colonial or ethnic ties with the Russian Federation. Common language and shared cultural traditions make communication and knowledge transfer convenient.

We also add a dummy indicator 'fincrisis2008' which takes the value of one for the period from 2008 onwards and zero prior to it.

The decision of whether, how much and where to invest can also be driven by institutional factors such as home and host levels of corruption, rule of law, governance, regulatory environment and political instability. Private Russian firms are thought to have transferred capital to offshore locations such as Cyprus during the 1990s to hedge against Russia's unstable political environment and economic volatility (Filippov, 2008). Although political stability has returned, corruption is still rampant in Russia, and the country consistently ranks low on global indices of corruption perception and economic freedom (Index of Economic Freedom, 2012; Transparency International, 2010).

Table 4 defines the variables and their sources as well as their expected signs, while Table 5 gives summary statistics of the selected variables.

\section{Insert table 4 here \\ Insert table 5 here}

These variables help distinguish between the four OFDI motives. Host per capita output relates to market seeking motive, while host country inflation refers to efficiency motive. In the presence of a positive association between OFDI and host GDP per capita, both the market and efficiency seeking motives can be expected. A negative relationship between OFDI and host inflation would however indicate preference for efficiency seeking motives, as higher inflation rate reduces the attractiveness of the host country for a cost-saving firm. Share of ores exports in the host country's exports receipts and number of patents issued annually are taken as proxies for resource and asset-seeking motives respectively. A positive 
association of either with Russian OFDI will suggest the presence of the corresponding investment motive.

\subsection{Methodology}

Model 1 explores asset exploiting motives by including indicators for market seeking, efficiency seeking and resource seeking motives, while model 2 tests for asset seeking motives in addition to asset exploiting motives. Our parsimonious baseline model can be given as:

ofdi $_{i, t}=f\left(\operatorname{lgdppccon}_{i, t}\right.$, infl $_{i, t}$, lexp $_{i, t}$, lrexrate $_{i, t}$, oressex $_{i, t}, \operatorname{lhgdpp}_{i, t}$, hinf $_{i, t}$, oecd $_{i, t}$, fincrisis2008 $\left._{i, t}\right)$

Where ' $i$ ' represents the host country and ' $t$ ' the year in which the investment took place.

In the subsequent models, we include various geographical, cultural and institutional variables for home and host countries.

Our final dataset is a panel of 49 countries containing 304 observations for the period 1999 2012. The list of countries is shown in Table A-1 in the appendix. We carry out a battery of econometric tests to examine our balanced panel dataset. Results of Breusch-Pagan Lagrange multiplier (LM) test, Wald test for groupwise heteroskedasticity, Wooldridge test for autocorrelation in panel data, and Variance Inflation Factors (VIF) for panel multicolinearity for the baseline specification are shown in Table A-2. The dataset is found to exhibit signs of serial autocorrelation and group wise heteroskedasticity. Use of Ordinary Least Squares (OLS) estimation would therefore be inefficient. Consequently, estimations are carried out using Feasible Generalized Least Squares (FGLS) panel regression. This technique allows estimations of models with autocorrelation within panels and cross-sectional correlation and heteroskedasticity across panels (Stata, 2013).

\section{Key findings}

Table 6 shows results for various OFDI model specifications. Column 1 gives results for the baseline specification while column 2 additionally tests for the host country technological level. Home and host country GDP per capita are found to be important determinants of Russian OFDI, both showing highly significant association with Russian TNCs' outward investments. This suggests that Russian OFDI flows weaken whenever the home economic activity falters, and increasing per capita income, in the presence of domestic institutional weaknesses, acts as a catalyst for Russian FDI outflows. This corroborates the finding of 
Kalotay and Sulstarova (2010) who found Russian domestic GDP to be the most important driver of Russian cross-border M\&A. Russia's exports to a country are likewise positively related with the amount of OFDI invested in the country by Russian firms. Russian TNCs prefer investing in countries with which they have prior exports experience. Home and host inflation rates, though significant, seem to play a minor role in driving Russian OFDI. Rising prices at home serve as a minor push factor for Russian outbound investments while host country price increases signal the economy's attractiveness. Abundance of natural resources in the host country as well as its technological prowess also show a significant positive association with Russian OFDI.

Real exchange rate too shows a positive sign, even though the level of significance is variable. Russian OFDI appears to increase in response to depreciation in the Russian Ruble, suggesting that Russian corporations take currency depreciation as a sign of upcoming economic volatility and would shift capital abroad. The binary variables for OECD and 2008 financial crisis are both significant with positive signs. The marginal probability of Russian firms engaging in outward investment in OECD countries is $32 \%$ compared with $18.8 \%$ for non-OECD countries. Similarly, post-2008-financial-crisis Russian OFDI, all things being equal, are $7 \%$ higher than the pre-crisis period.

\section{Insert table 6 here}

These findings shed light on the possible motives behind Russian OFDI. A strong positive association of host GDP per capita with Russian OFDI suggests the importance of capturing foreign markets for Russian TNCs. As discussed in Section 2, many overseas investments by Russian firms in OECD, CIS and other countries have sought to acquire higher share in foreign markets through downstream integration and bypassing import quotas. Host output's positive association with OFDI can also arise as a result of efficiency-seeking motives, which are also linked with a negative relationship between OFDI and host inflation rates. Rising host country prices can indicate higher production costs which may deter cost saving investments by foreign firms. A significant positive association with host country inflation rates (instead of an expected negative sign) suggests that efficiency is not a major investment motive of Russian OFDI.

Another investment motive for Russian TNCs may be to acquire access to natural resources abroad, both to facilitate home industrial production and to exploit host countries' mineral 
wealth using firms' technical knowhow. This motive can be deduced from the significant positive association between host country share of commodities in their total exports receipts. The desire to improve firms' long run competitiveness is evident in the significant and positive coefficient for the number of patents obtained in the host countries (Table 6 column 2), as Russian TNCs seem to invest more in economies placed at the cutting edge of technology. The results, taken together, suggest that in the case of Russian TNCS, both asset exploiting and asset augmenting motives are at play.

We re-estimate our baseline model by including some additional factors that have been examined in the literature. Columns $3-6$ of Table 6 show results with various geographical and cultural factors. Distance between the largest cities of the home and the host country, taken as an indicator of geographical proximity exhibits a significant positive association with Russian OFDI, suggesting that Russian TNCs make more substantial acquisitions at more distant destinations such as North America and Western Europe as compared to Russia's near abroad where Russian investments, even though numerous, are often less valuable. This observation is also reflected in the statistically insignificant coefficient for the CIS dummy. It is possible that Russian TNCs prefer investing in countries neighbouring Russia, regardless of those countries being former Soviet Republics. Results do not support this argument, as the binary variable for host country's geographical contiguity with Russia is likewise insignificant. Furthermore, the common language dummy used as an indicator of cultural affinity is also insignificant. These results confirm the observation that CIS countries, many of which still maintain Russian as an important official or administrative language, and some of which are located nearby, are no more the main targets of Russian OFDI.

\section{Insert table 7 here \\ Insert table 8 here}

Table 7 shows the role of home country institutional indicators on Russian OFDI. Home institutional factors, such as rule of law, quality of governance and corruption play a significant role in driving Russian OFDI. Poor institutional environment pushes Russian TNCS to invest surplus capital abroad. Political instability at home however does not seem to play a significant role. In the same vein, Russian TNCs do not seem to take host levels of corruption into account while making their investment decisions (Table 8). This may owe to the fact that Russian TNCs have grown during the last couple of decades under a political 
system marred by corruption and arbitrariness, and perceived corruption in a country does not hamper their outward investment ambitions. Other host institutional factors likewise show no statistically significant association with Russian OFDI.

In the light of the above findings, Russian OFDI can be compared to foreign investments by TNCs of other emerging countries. Like Brazilian and Chinese firms, and especially like Indian firms, Russian TNCs accord high importance to host country market size (Amal and Tomio, 2012; De Beule and Den Bulcke, 2012). Similarly, natural resources potential of the host countries plays a substantial positive role in attracting Russian OFDI, just as it does for Chinese and Indian OFDI (Buckley et al., 2007; De Beule and Den Bulcke, (2012; Kolstad and Wiig, 2009). In addition, both Russian and Chinese TNCs seem keen to invest in countries that are already a significant market for their products (Ramasamy et al., 2012).

However, some differences are also noticeable in the Russian investment strategy. Unlike Brazilian and Chinese firms, Russian firms appear to increase their outward investments in response to the depreciation of national currency (Amal and Tomio, 2012; Zhang and Daly, 2011). Likewise, in contrast with Indian TNCs which cherish economic freedom aspects of host economies such as government size, ease of foreign trade, and market regulations (Anwar and Mughal, 2012), Russian firms do not appear to give importance to rule of law, governance or level of corruption in the host economy. Moreover, similar to Brazilian OFDI but unlike Chinese and Indian investments, Russian OFDI are positively associated with the geographical distance between the home and the host country (Amal and Tomio, 2012; De Beule and Den Bulcke, 2012).

\section{Concluding remarks}

In the recent years, growth of OFDI flows from emerging economies has outpaced those from the OECD countries (Amal and Tomio, 2012). In this study, we examined one of the biggest sources of OFDI from emerging countries, namely Russia. Using S\&P data on Russian firms' foreign mergers and acquisitions, we analyzed the home and host country economic, geographical, cultural and institutional factors that influence Russian OFDI, and gauged the importance of various investment motives. We found that both push and pull factors are at play in driving Russian outbound investments. Results suggest that home and host per capita output and inflation as well as abundance of natural resources in the host country play a significant role in driving Russian TNCs foreign investment decisions. Exports to a country 
also increase Russian OFDI to the host country, while host country institutions have little effect on Russian OFDI. The 2008 global financial crisis appears to have raised Russian TNCs appetite for foreign assets. All things being equal, Russian TNCs are keener to invest in OECD countries than in CIS countries.

Our findings suggest that Russian outward investments seek to acquire and augment strategic assets as well as exploiting their existing asset endowments. Raising share in foreign markets is an important objective of Russian firms. Seeking access to host country's natural resources and technology acquisition also appear to be important motives, while efficiency does not appear to be Russian firms' foremost priority at the moment. Given the fact that multinationals from other emerging economies are also actively seeking foreign markets and access to natural resources, Russian firms could in future face increasing competition in pursuit of their investment objectives.

\section{Acknowledgement}

We wish to express our deep gratitude to Prof. Martin Moy for proof-reading and his helpful comments, although any errors are our own. This research was supported by Cape Breton University grant number: RP 8701.

\section{References}

Amal, M., \& Tomio, B. T. (2012). Determinants of Brazilian Outward Foreign Direct Investment (OFDI): A Host Country Perspective.

Andreff, W. (2013). Maturing Strategies of Russian Multinational Companies: Comparison with Chinese Multinationals. Foreign Investment: The World Scientific Reference on Globalisation in Eurasia and the Pacific Rim, London, Imperial College Press/World Scientific.

Anwar, A. I. (2009). The push and pull factors of the Indian outward foreign direct investment. Unpublished PhD dissertation. Universität Leipzig Bibliothek

Anwar, A. I., \& Mughal, M. (2012). Economic Freedom and Indian Outward Foreign Direct Investment: An Empirical Analysis. Economics Bulletin, 32(4), 2991-3007. 
Anwar, A., \& Mughal, M. (2013). The role of diaspora in attracting Indian outward FDI. International Journal of Social Economics, 40(11), 944-955.

Buckley, P. J., Clegg, L. J., Cross, A. R., Liu, X., Voss, H., \& Zheng, P. (2007). The determinants of Chinese outward foreign direct investment. Journal of International Business Studies, 38(4), 499-518.

De Beule, F., \& Van Den Bulcke, D. (2012). 3 The impact of the global economic crisis on foreign direct investment. Towards a New Development Paradigm in Twenty-First Century China: Economy, Society and Politics, 49.

Dunning, J. (1988). The eclectic paradigm of international production: a restatement and some possible extensions. Journal of International Business Studies, 19(1), 1-31.

Dunning, J. H. (1993). The Theory of Transnational Corporations. Routledge.

Dunning, J. H., \& Norman, G. (1979). Factors influencing the location of multinational enterprises. Economists Advisory Group.

Filippov, S. (2010). Russian companies: the rise of new multinationals. International Journal of Emerging Markets, 5(3/4), 307-332.

Filippov, S. (2011). Russia's emerging multinational companies amidst the global economic crisis. UNU-MERIT, Maastricht Economic and Social Research and Training Centre on Innovation and Technology.

Kalotay, K. (2010). The future of Russian outward foreign direct investment and the eclectic paradigm: What changes after the crisis of 2008-2009. Competitio (University of Debrecen), 9(1), 31-54.

Kolstad, I., \& Wiig, A. (2009). Is transparency the key to reducing corruption in resource-rich countries? World Development, 37(3), 521-532.

Kumar, K. (1982). Third world multinationals: a growing force in international relations. International Studies Quarterly, 397-424.

Kumar, K. (1982). Third world multinationals: a growing force in international relations. International Studies Quarterly, 397-424. 
Kuznetsov, A. (2010). Industrial and geographical diversification of Russian foreign direct investments. Turku School of Economics Pan-European Institute Electronic Publication, (7).

Kuznetsov, A., \& Chetverikova, A. (2009). Russian multinationals continue their outward expansion in spite of the global crisis.

Kuznetsov, A., \& Chetverikova, A. (2009). Russian multinationals continue their outward expansion in spite of the global crisis. Retrieved from http://academiccommons.columbia.edu/catalog/ac:135515

Makino,S, Lau, C.M, \& Yeh, R.S. (2002). Asset Exploitation vs Asset seeking: Implications for location choice of foreign Direct Investment from Newly Industrialized Economies. Journal of international Business Studies, 33(3), 403-421.

Ramasamy, B., Yeung, M., \& Laforet, S. (2012). China's outward foreign direct investment: Location choice and firm ownership. Journal of World Business, 47(1), 17-25.

Shige Makino, Chung-Ming Lau, \& Rhy-Song Yeh. (2002.). Asset Exploitation vs Asset seeking: Implications for location choice of foreign

Skolkovo Research. (n.d.). Emerging Russian Multinationals: Achievements and Challenges. Skolkovo Research.

Stata. (2013). Stata Manual on Panel Data.

The Heritage Foundation. (2014). Index of Economic Freedom. Retrieved on Feb. 13, 2014, from http://www.heritage.org/index/country/russia

Transparency International (2010). The Corruption Perception Index 2010, available at: http://www.transparency.org.

United Nations Conference on Trade and Development. (2005). World Investment Report: Transnational Corporations and the Internationalization of $R \& D$.

United Nations Conference on Trade and Development. (2006). World Investment Report: FDI from Developing and Transition Economies: Implications for Development. 
United Nations Conference on Trade and Development. (2006). World Investment Report: FDI from Developing and Transition Economies: Implications for Development. New York and Geneva: United Nations.

United Nations Conference on Trade and Development. (2007). World Investment Report: Transnational Corporations, Extractive Industries and Development.

United Nations Conference on Trade and Development. (2013). World Investment Report: Global Value Chains: Investment and Trade for Development.

Zhang, X., \& Daly, K. (2011). The determinants of China's outward foreign direct investment. Emerging Markets Review, 12(4), 389-398. 
Table 1: Top Russian Firms in Global 500

Rank

CompanyName

\begin{tabular}{llcccc}
\hline 21 & Gazprom & 153.5 & 395.2 & 417000 & 274796.0 \\
\hline 46 & Lukoil & 116.3 & 99.0 & 150000 & 73207.0 \\
\hline 99 & Rosneft Oil & 79.6 & 126.3 & 166110 & 73024.0 \\
\hline 228 & Sberbank & 44.8 & 494.4 & 286019 & 52754.0 \\
\hline 308 & Sistema & 35.4 & 44.7 & 170000 & 9195.0 \\
\hline 358 & TNK-BP International & 31.7 & 43.3 & 50000 & 22477.0 \\
\hline 445 & Surgutneftegas & 26.3 & 58.8 & 101765 & 55338.0 \\
\hline
\end{tabular}


TABLE 2: Top 20 Russian MNCs outward foreign direct investments through M \& A during 1999 to 2013

\begin{tabular}{|c|c|c|c|c|c|c|c|}
\hline Buyers & Primary Industry & Host Country & $\begin{array}{l}\text { Number } \\
\text { of } \\
\text { M\&A }\end{array}$ & $\begin{array}{l}\text { Total OFDI } \\
\text { through } \\
\text { M\&A (\$ } \\
\text { mm) }\end{array}$ & $\begin{array}{l}\text { Total } \\
\text { Assets (\$ } \\
\text { mm)- } \\
\text { Latest } \\
\text { Annual }\end{array}$ & $\begin{array}{c}\text { Total } \\
\text { Revenue (\$ } \\
\text { mm)- } \\
\text { Latest } \\
\text { Annual }\end{array}$ & $\begin{array}{l}\text { Number } \\
\text { of } \\
\text { Employees }\end{array}$ \\
\hline $\begin{array}{l}\text { Oil company } \\
\text { LUKOIL }\end{array}$ & Energy & $\begin{array}{l}\text { Belgium, Bulgaria, Canada, Finland, } \\
\text { Gabon, Guinea, Iraq, Italy, Ivory } \\
\text { Coast, Netherlands, Poland, Romania, } \\
\text { Serbia, Sierra Leone, Turkey< United } \\
\text { States }\end{array}$ & 23 & 7022.33 & 109439 & 141452 & \\
\hline JSC VTB Bank & Financials & $\begin{array}{l}\text { Armenia, Austria, Azerbaijan, } \\
\text { Belarus, France, Georgia, Germany, } \\
\text { Luxembourg, Serbia, Ukraine, United } \\
\text { Kingdom }\end{array}$ & 21 & 1660.67 & 266872.6 & 10107.6 & 103808 \\
\hline Gazprom & Energy & $\begin{array}{l}\text { Armenia, Austria, Belarus, Cyprus, } \\
\text { Finland, Germany, Latvia, Lithuania, } \\
\text { Moldova, Serbia, Switzerland }\end{array}$ & 16 & 5265.3 & 395145.5 & 157026.6 & 417000 \\
\hline $\begin{array}{l}\text { United Company } \\
\text { RUSAL Plc }\end{array}$ & Materials & $\begin{array}{l}\text { Australia, China, Guinea, Guyana, } \\
\text { Italy, Jamaica, Kazakhstan, } \\
\text { Montenegro, Nigeria, Switzerland, } \\
\text { Tajikistan }\end{array}$ & 16 & 634.93 & 20580 & 9760 & 69060 \\
\hline Severstal & Materials & $\begin{array}{l}\text { Italy, Kazakhstan, Ukraine, United } \\
\text { States }\end{array}$ & 15 & 3683.46 & 14533.7 & 13311.6 & 100000 \\
\hline $\begin{array}{l}\text { International } \\
\text { Marketing \& Sales } \\
\text { Group PLC }\end{array}$ & $\begin{array}{l}\text { Consumer } \\
\text { Discretionary }\end{array}$ & $\begin{array}{l}\text { Greece, Hungary, India, Romania, } \\
\text { Sweden, Turkey, United Kingdom }\end{array}$ & 13 & 111.52 & & & 2049 \\
\hline Gazprom Neft & Energy & $\begin{array}{l}\text { Cyprus, Italy, Kazakhstan, } \\
\text { Kyrgyzstan, Serbia, United Kingdom }\end{array}$ & 13 & 2039 & 47589.8 & 38580 & \\
\hline Sberbank & Financials & $\begin{array}{l}\text { Austria, Belarus, Hungary, } \\
\text { Kazakhstan, Switzerland, Turkey, } \\
\text { Ukraine, United States }\end{array}$ & 12 & 4999.09 & 554237.4 & 30697.1 & 306123 \\
\hline Mobile Telesystems & $\begin{array}{l}\text { Telecommunication } \\
\text { Services }\end{array}$ & $\begin{array}{l}\text { Armenia, Bermuda Cyprus, } \\
\text { Netherlands, Ukraine, United States, } \\
\text { Uzbekistan }\end{array}$ & 12 & 1325.29 & 14777.1 & 12126.8 & 62077 \\
\hline $\begin{array}{l}\text { Federal Grid } \\
\text { Company of Unified } \\
\text { Energy System }\end{array}$ & Utilities & Georgia, Ukraine & 11 & & 27955 & 4807.9 & 11181 \\
\hline GAZTek & Utilities & Ukraine & 10 & 22.001 & 1398.1 & 16.2 & \\
\hline
\end{tabular}




\begin{tabular}{|c|c|c|c|c|c|c|c|}
\hline Buyers & Primary Industry & Host Country & $\begin{array}{l}\text { Number } \\
\text { of } \\
\text { M\&A }\end{array}$ & $\begin{array}{c}\text { Total OFDI } \\
\text { through } \\
\text { M\&A (\$ } \\
\text { mm) }\end{array}$ & $\begin{array}{c}\text { Total } \\
\text { Assets (\$ } \\
\text { mm)- } \\
\text { Latest } \\
\text { Annual }\end{array}$ & $\begin{array}{c}\text { Total } \\
\text { Revenue (\$ } \\
\text { mm)- } \\
\text { Latest } \\
\text { Annual }\end{array}$ & $\begin{array}{l}\text { Number } \\
\text { of } \\
\text { Employees }\end{array}$ \\
\hline Gazprombank & Financials & $\begin{array}{l}\text { Armenia, Austria, Cyprus, Czech, } \\
\text { Republic, Ireland, Moldova, } \\
\text { Switzerland }\end{array}$ & 9 & 429.58 & 110997.2 & 3501.4 & 7513 \\
\hline $\begin{array}{l}\text { Renova Group of } \\
\text { Companies }\end{array}$ & Financials & $\begin{array}{l}\text { Belarus, South Africa, Sweden, } \\
\text { Switzerland }\end{array}$ & 8 & 112.07 & & & \\
\hline Pharmstandard & Healthcare & $\begin{array}{l}\text { Cyprus, Latvia, Luxembourg, } \\
\text { Singapore, Ukraine }\end{array}$ & 8 & 705.23 & 1746.8 & 1573.9 & \\
\hline $\begin{array}{l}\text { Mining and } \\
\text { Metallurgical } \\
\text { Company Norilsk } \\
\text { Nickel }\end{array}$ & Materials & $\begin{array}{l}\text { Australia, Canada, Cyprus, Finland, } \\
\text { Saint Kitts \& Nevis, United Kingdom }\end{array}$ & 8 & 6617.45 & 18781 & 11489 & 84082 \\
\hline Oil Company Rosneft & Energy & $\begin{array}{l}\text { Canada, Cyprus, Germany, Mongolia, } \\
\text { United Kingdom, Venezuela }\end{array}$ & 8 & 1785.04 & 229421.9 & 138359.2 & 170900 \\
\hline Altimo & Financials & $\begin{array}{l}\text { Cambodia, Cyprus, Kyrgyzstan, } \\
\text { Netherlands, United States, } \\
\text { Uzbekistan }\end{array}$ & 8 & 5042 & & & \\
\hline OAO VAO Intourist & $\begin{array}{l}\text { Consumer } \\
\text { Discretionary }\end{array}$ & $\begin{array}{l}\text { Czech Republic, Italy, Namibia, } \\
\text { Turkey, United Kingdom, United } \\
\text { States }\end{array}$ & 8 & & & 14 & \\
\hline RusNano & Financials & $\begin{array}{l}\text { British Virgin Islands, Cyprus, } \\
\text { Finland, Netherlands, United States }\end{array}$ & 7 & 32.978 & & 59.9 & 409 \\
\hline $\begin{array}{l}\text { CJSC } \\
\text { Transmashholding }\end{array}$ & Industrials & $\begin{array}{l}\text { Germany, Kazakhstan, Latvia, } \\
\text { Switzerland }\end{array}$ & 7 & 60 & & 1277.4 & 251 \\
\hline ОАО ТМК & Energy & $\begin{array}{l}\text { Germany, Italy, Kazakhstan, Oman, } \\
\text { Romania, United States }\end{array}$ & 7 & 1846.68 & 7418.7 & 6431.9 & 516 \\
\hline
\end{tabular}

Source: Authors’ calculation based on S\&P Capital database (2013) 
Table 3 - Top 20 Host Countries before and after Financial Crisis

\begin{tabular}{|c|c|c|c|}
\hline \multicolumn{2}{|r|}{ Before Financial Crisis } & \multicolumn{2}{|r|}{ During Financial Crisis } \\
\hline Country & Russian OFDI (\$ mm) from 1999 to 2007 & Country & Russian OFDI (\$ mm) from 2008 to 2013 \\
\hline Canada & 6175.5 & Netherlands & 10540.1 \\
\hline France & 2817.3 & United States & 6372.4 \\
\hline Belarus & 2532.2 & Turkey & 4403.5 \\
\hline Cyprus & 2523.0 & Italy & 3596.6 \\
\hline Kazakhstan & 2342.0 & $\begin{array}{l}\text { United } \\
\text { Kingdom }\end{array}$ & 3130.3 \\
\hline United States & 2045.6 & Belarus & 2812.9 \\
\hline Netherlands & 1731.2 & Germany & 2503.7 \\
\hline Ukraine & 1286.2 & Cyprus & 2354.8 \\
\hline $\begin{array}{l}\text { United } \\
\text { Kingdom }\end{array}$ & 918.1 & Hungary & 1802.6 \\
\hline Luxembourg & 850.3 & China & 1600.0 \\
\hline Italy & 837.3 & Canada & 1449.1 \\
\hline Australia & 536.2 & Austria & 1232.7 \\
\hline Armenia & 442.8 & Belgium & 1185.9 \\
\hline Turkey & 407.7 & Serbia & 1072.8 \\
\hline Uzbekistan & 372.3 & France & 1040.7 \\
\hline Finland & 356.0 & Australia & 925.5 \\
\hline Serbia & 231.0 & Luxembourg & 600.0 \\
\hline Norway & 225.9 & Singapore & 590.0 \\
\hline Kyrgyzstan & 205.8 & Ukraine & 548.6 \\
\hline Austria & 200.1 & Kazakhstan & 489.0 \\
\hline
\end{tabular}

Source: Authors' calculation based on S\&P Capital database (2013) 
Table 4: description of variables and their sources

\begin{tabular}{|c|c|c|c|}
\hline Variables & Explanation & $\begin{array}{l}\text { Expected } \\
\text { Sign }\end{array}$ & Data Source \\
\hline ofdi & $\begin{array}{l}\text { Amount of Russian OFDI (\$ billion) through } \\
\text { M\&A to the host country }\end{array}$ & & S\&P Capital IQ Database (2013) \\
\hline lgdppccon & Log of GDP per capita constant (2005) & + & World Bank Development Indicators (2013) \\
\hline lgdpdef & Log of GDP Deflator & - & World Bank Development Indicators (2013) \\
\hline lrexrate & $\begin{array}{l}\text { Log of Russian Rouble official annual } \\
\text { average exchange rate (with respect to US\$) }\end{array}$ & - & World Bank Development Indicators (2013) \\
\hline oresex & $\begin{array}{l}\text { ratio of ore and metals exports to total host } \\
\text { country merchandise exports }\end{array}$ & + & World Bank Development Indicators (2013) \\
\hline lexp & Russia’s exports to the host country & + & $\begin{array}{l}\text { United Nations Commodity Trade Statistics } \\
\text { Database (2013) }\end{array}$ \\
\hline lhgdpcon & Russian GDP constant (2005) & $-/+$ & World Bank Development Indicators (2013) \\
\hline lhgdpgrow & Growth of Russian GDP & $-/+$ & World Bank Development Indicators (2013) \\
\hline hinf & Home country inflation & + & World Bank Development Indicators (2013) \\
\hline lpatents & $\begin{array}{l}\text { Log of number of patents issued by the host } \\
\text { country }\end{array}$ & + & World Bank Development Indicators (2013) \\
\hline hcorruption & Control on Corruption (home country) & - & World Bank Governance Indicators (2013) \\
\hline hpolstability & Index for Political Stability (home country) & - & World Bank Governance Indicators (2013) \\
\hline hgovernance & Index for Good Governance (home country) & - & World Bank Governance Indicators (2013) \\
\hline hruleoflaw & Index for Rule of Law (home country) & - & World Bank Governance Indicators (2013) \\
\hline hregulatory & Index for Regulatory Quality (home country) & - & World Bank Governance Indicators (2013) \\
\hline cis & $\begin{array}{l}\text { CIS }=1 \text { if Russian investment is in } \\
\begin{aligned} \text { Commonwealth of Independent States } \\
\quad=0 \text { otherwise }\end{aligned}\end{array}$ & + & United Nations (2013) \\
\hline fincrisis 2008 & $\begin{aligned} \mathrm{FC} & =1 \text { if year }>=2008 \\
& =0 \text { otherwise }\end{aligned}$ & - & \\
\hline Oecd & $\begin{array}{l}\text { OECD = } 1 \text { if investment destination is an } \\
\text { OECD country } \\
\quad=0 \text { otherwise }\end{array}$ & - & OECD (2013) \\
\hline corruption & $\begin{array}{l}\text { Index for Control on Corruption (host } \\
\text { country) }\end{array}$ & + & World Bank Governance Indicators (2013) \\
\hline governance & Index for Good Governance (host country) & + & World Bank Governance Indicators (2013) \\
\hline ruleoflaw & Index for Rule of Law (host country) & + & World Bank Governance Indicators (2013) \\
\hline polstability & Index for Political Stability (host country) & + & World Bank Governance Indicators (2013) \\
\hline regulatory & Index for Regulatory Quality (host country) & + & World Bank Governance Indicators (2013) \\
\hline Contig & $\begin{array}{l}1 \text { if investment destination is geographically } \\
\text { contiguous } 0 \text { otherwise }\end{array}$ & + & CEPII Database (2013) \\
\hline comlang_et o & $\begin{array}{l}1 \text { if a language is spoken by at least } 9 \% \text { of the } \\
\text { population in both countries; otherwise } 0\end{array}$ & + & CEPII Database (2013) \\
\hline Idistance & simple distance (most populated cities, km) & - & CEPII Database (2013) \\
\hline
\end{tabular}

All monetary values are in constant (2005) US\$ prices. 
Table 5: Summary Statistics

\begin{tabular}{|c|c|c|c|c|}
\hline & mple xtgls & Number of obs = & 304 & \\
\hline Variable & Mean & Std. Dev. & Min & Max \\
\hline ofdi & 0.32 & 0.92 & 0.10 & 8.82 \\
\hline Igdppccon & 9.54 & 1.26 & 5.72 & 11.38 \\
\hline infl & 5.70 & 9.16 & -32.81 & 74.85 \\
\hline lexp & 21.64 & 2.04 & 11.01 & 25.05 \\
\hline Irexrate & 4.62 & 0.08 & 4.34 & 4.91 \\
\hline oresex & 6.46 & 9.00 & 0.00 & 82.23 \\
\hline lhgdppc & 8.57 & 0.22 & 8.17 & 8.83 \\
\hline hinf & 19.87 & 16.56 & 1.99 & 72.39 \\
\hline oecd & 0.59 & 0.49 & 0.00 & 1.00 \\
\hline fincris 2008 & 0.54 & 0.50 & 0.00 & 1.00 \\
\hline lpatents & 7.88 & 2.19 & 2.08 & 13.13 \\
\hline cis & 0.13 & 0.34 & 0.00 & 1.00 \\
\hline contig & 0.16 & 0.37 & 0.00 & 1.00 \\
\hline comlang_et $\sim 0$ & 0.08 & 0.28 & 0.00 & 1.00 \\
\hline Idistance & 8.07 & 0.60 & 7.31 & 9.50 \\
\hline hruleoflaw & -0.91 & 0.10 & -1.13 & -0.74 \\
\hline hcorruption & -0.93 & 0.11 & -1.09 & -0.71 \\
\hline hgovernance & -0.49 & 0.15 & -0.77 & -0.34 \\
\hline hpolstabil $\sim y$ & -1.05 & 0.22 & -1.46 & -0.76 \\
\hline hregulatory & -0.35 & 0.12 & -0.56 & -0.11 \\
\hline ruleoflaw & 0.50 & 1.03 & -1.54 & 2.00 \\
\hline corruption & 0.53 & 1.15 & -1.83 & 2.59 \\
\hline governance & 0.63 & 1.07 & -2.26 & 2.43 \\
\hline polstability & 0.28 & 0.88 & -2.37 & 1.67 \\
\hline regulatory & 0.58 & 1.02 & -2.53 & 2.20 \\
\hline
\end{tabular}




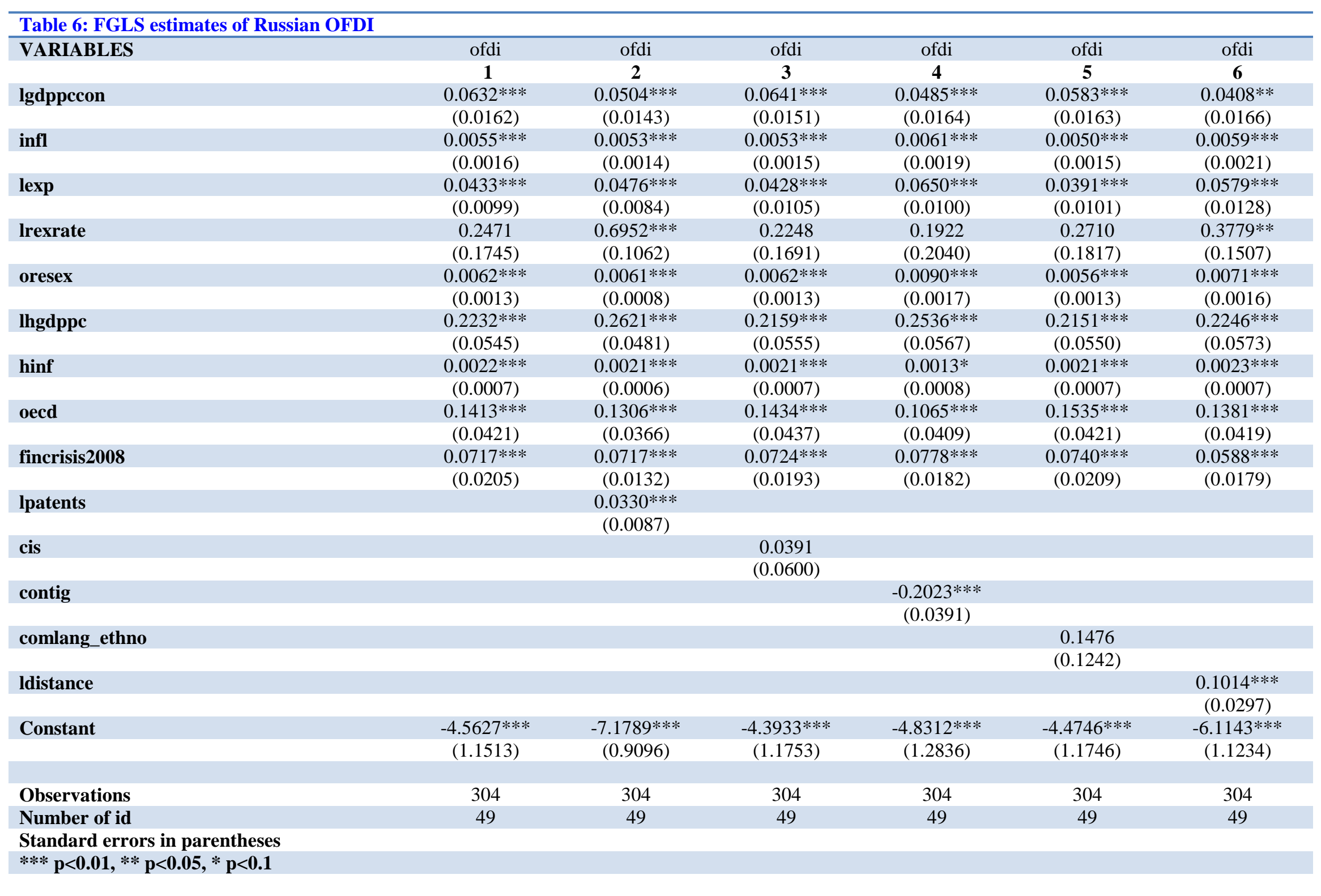




\begin{tabular}{|c|c|c|c|c|c|c|}
\hline VARIABLES & $\begin{array}{c}\text { (1) } \\
\text { ofdi }\end{array}$ & $\begin{array}{c}(2) \\
\text { ofdi } \\
\end{array}$ & $\begin{array}{l}\text { (3) } \\
\text { ofdi }\end{array}$ & $\begin{array}{l}\text { (4) } \\
\text { ofdi } \\
\end{array}$ & $\begin{array}{l}(5) \\
\text { ofdi }\end{array}$ & $\begin{array}{l}(6) \\
\text { ofdi } \\
\end{array}$ \\
\hline lgdppccon & $\begin{array}{c}0.0632 * * * \\
(0.0162)\end{array}$ & $\begin{array}{c}0.0365 * * \\
(0.0185)\end{array}$ & $\begin{array}{c}0.0677 * * * \\
(0.0164)\end{array}$ & $\begin{array}{c}0.0624 * * * \\
(0.0192)\end{array}$ & $\begin{array}{c}0.0598 * * * \\
(0.0159)\end{array}$ & $\begin{array}{c}0.0619 * * * \\
(0.0181)\end{array}$ \\
\hline infl & $\begin{array}{c}0.0055^{* * *} \\
(0.0016)\end{array}$ & $\begin{array}{l}0.0046^{*} \\
(0.0028)\end{array}$ & $\begin{array}{c}0.0053 * * * \\
(0.0017)\end{array}$ & $\begin{array}{l}0.0038^{*} \\
(0.0020)\end{array}$ & $\begin{array}{c}0.0053 * * * \\
(0.0017)\end{array}$ & $\begin{array}{c}0.0048 * * * \\
(0.0018)\end{array}$ \\
\hline lexp & $\begin{array}{c}0.0433 * * * \\
(0.0099)\end{array}$ & $\begin{array}{c}0.0365 * * * \\
(0.0109)\end{array}$ & $\begin{array}{c}0.0433 * * * \\
(0.0098)\end{array}$ & $\begin{array}{c}0.0492 * * * \\
(0.0092)\end{array}$ & $\begin{array}{c}0.0423 * * * \\
(0.0098)\end{array}$ & $\begin{array}{c}0.0399 * * * \\
(0.0103)\end{array}$ \\
\hline lrexrate & $\begin{array}{c}0.2471 \\
(0.1745)\end{array}$ & $\begin{array}{c}0.5214 * * \\
(0.2336)\end{array}$ & $\begin{array}{c}0.2609 \\
(0.1753)\end{array}$ & $\begin{array}{c}0.2698 \\
(0.1947)\end{array}$ & $\begin{array}{c}0.2737 \\
(0.1736)\end{array}$ & $\begin{array}{c}0.3864^{*} \\
(0.1995)\end{array}$ \\
\hline oresex & $\begin{array}{c}0.0062 * * * \\
(0.0013)\end{array}$ & $\begin{array}{c}0.0059 * * * \\
(0.0017)\end{array}$ & $\begin{array}{c}0.0064 * * * \\
(0.0013)\end{array}$ & $\begin{array}{c}0.0075^{* * *} \\
(0.0017)\end{array}$ & $\begin{array}{c}0.0063 * * * \\
(0.0012)\end{array}$ & $\begin{array}{c}0.0066^{* * *} \\
(0.0018)\end{array}$ \\
\hline lhgdppc & $\begin{array}{c}0.2232 * * * \\
(0.0545)\end{array}$ & $\begin{array}{c}0.4502^{* * *} \\
(0.1054)\end{array}$ & $\begin{array}{c}0.1900 * * * \\
(0.0587)\end{array}$ & $\begin{array}{c}0.3276 * * * \\
(0.0619)\end{array}$ & $\begin{array}{c}0.1985 * * * \\
(0.0604)\end{array}$ & $\begin{array}{c}0.2132 * * * \\
(0.0501)\end{array}$ \\
\hline hinf & $\begin{array}{c}0.0022 * * * \\
(0.0007)\end{array}$ & $\begin{array}{c}0.0024 * * * \\
(0.0008)\end{array}$ & $\begin{array}{c}0.0021 * * * \\
(0.0007)\end{array}$ & $\begin{array}{c}0.0017 * * * \\
(0.0006)\end{array}$ & $\begin{array}{c}0.0020 * * * \\
(0.0007)\end{array}$ & $\begin{array}{c}0.0024 * * * \\
(0.0007)\end{array}$ \\
\hline oecd & $\begin{array}{c}0.1413 * * * \\
(0.0421)\end{array}$ & $\begin{array}{c}0.1568 * * * \\
(0.0422)\end{array}$ & $\begin{array}{c}0.1270 * * * \\
(0.0437)\end{array}$ & $\begin{array}{c}0.1333 * * \\
(0.0528)\end{array}$ & $\begin{array}{c}0.1529 * * * \\
(0.0402)\end{array}$ & $\begin{array}{c}0.1246 * * \\
(0.0523)\end{array}$ \\
\hline fincrisis2008 & $\begin{array}{c}0.0717 * * * \\
(0.0205)\end{array}$ & $\begin{array}{c}0.0251 \\
(0.0172)\end{array}$ & $\begin{array}{c}0.0749 * * * \\
(0.0206)\end{array}$ & $\begin{array}{c}0.0840 * * * \\
(0.0157)\end{array}$ & $\begin{array}{c}0.0754 * * * \\
(0.0195)\end{array}$ & $\begin{array}{c}0.0622 * * * \\
(0.0189)\end{array}$ \\
\hline hruleoflaw & & $\begin{array}{c}-0.7396 * * * \\
(0.1883)\end{array}$ & & & & \\
\hline hcorruption & & & $\begin{array}{l}-0.0967 * \\
(0.0528)\end{array}$ & & & \\
\hline hgovernance & & & & $\begin{array}{l}-0.1531^{*} \\
(0.0914)\end{array}$ & & \\
\hline hpolstability & & & & & $\begin{array}{c}0.0244 \\
(0.0260)\end{array}$ & \\
\hline hregulatory & & & & & & $\begin{array}{c}-0.2292 * * * \\
(0.0553)\end{array}$ \\
\hline Constant & $\begin{array}{c}-4.5627 * * * \\
(1.1513)\end{array}$ & $\begin{array}{c}-8.0680 * * * \\
(1.5391)\end{array}$ & $\begin{array}{c}-4.4633^{* * *} \\
(1.1548)\end{array}$ & $\begin{array}{c}-5.7328 * * * \\
(1.1905)\end{array}$ & $\begin{array}{c}-4.3946 * * * \\
(1.1734)\end{array}$ & $\begin{array}{c}-5.1040 * * * \\
(1.1894)\end{array}$ \\
\hline Observations & 304 & 304 & 304 & 304 & 304 & 304 \\
\hline Number of id & 49 & 49 & 49 & 49 & 49 & 49 \\
\hline
\end{tabular}

*** $\mathrm{p}<0.01, * * \mathrm{p}<0.05, * \mathrm{p}<0.1$ 


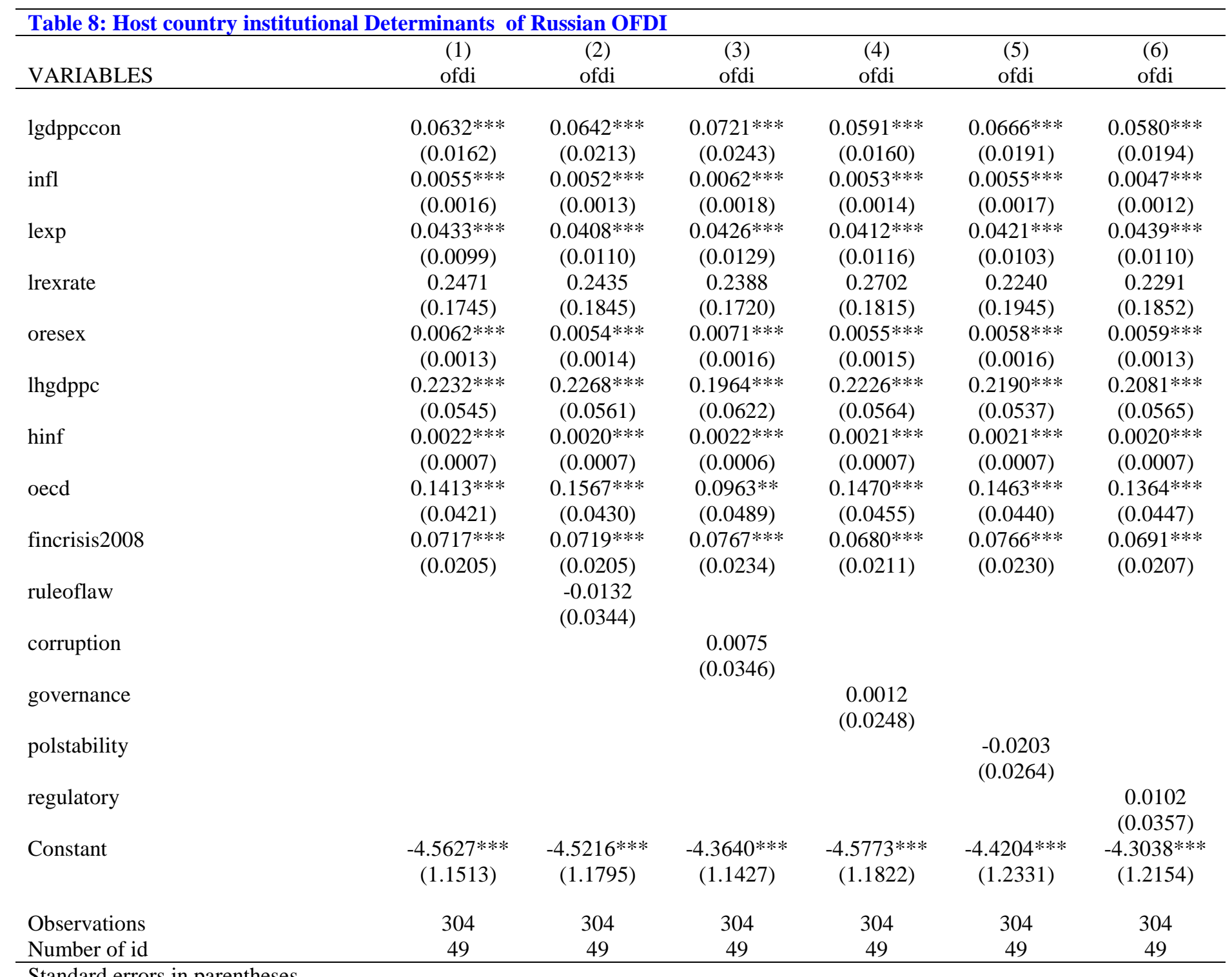

Standard errors in parentheses

*** $\mathrm{p}<0.01, * * \mathrm{p}<0.05, * \mathrm{p}<0.1$ 


\section{Table 1-A: $\quad$ List of Countries}

Armenia, Australia, Austria, Belarus, Belgium, British Virgin Islands, Bulgaria, Canada, Channel Islands, China, Croatia, Cyprus, Czech Republic, Denmark, Egypt, Estonia, Finland, France, Georgia, Germany, Greece, Guinea, Hong Kong, Hungary, India, Israel, Italy, Jamaica, Kazakhstan, Kyrgyzstan, Latvia, Lithuania, Luxembourg, Moldova, Montenegro, Netherlands, Nigeria, Norway, Oman, Peru, Poland, Portugal, Romania, Serbia, Seychelles, Singapore, Slovenia, South Korea, South Africa, Spain, Sweden, Switzerland, Turkey, Ukraine, United Kingdom, United State of America, Uzbekistan

\section{OECD Countries:}

Australia, Austria, Belgium, Canada, Czech Republic, Denmark, Estonia, Finland, France, Germany, Greece, Hungary, Israel, Italy, Luxembourg, Netherlands, Norway, Poland, Portugal, Slovenia, South Korea, Spain, Sweden, Switzerland, Turkey, United Kingdom, United States of America

Non-OECD Countries:

Armenia, Belarus, British Virgin Islands, Bulgaria, Channel Islands, China, Croatia, Cyprus, Egypt, Georgia, Guinea, Hong Kong, India, Jamaica, Kazakhstan, Kyrgyzstan, Latvia, Lithuania, Moldova, Montenegro, Nigeria, Oman, Peru, Romania, Serbia, Seychelles, Singapore, South Africa, Ukraine, Uzbekistan

\section{Table A-2}

Wooldridge test for autocorrelation in panel data

H0: no first-order autocorrelation

$$
\begin{aligned}
& \mathrm{F}(1,28)=3.663 \\
& \text { Prob }>F=0.0459
\end{aligned}
$$

Modified Wald test for groupwise heteroskedasticity

in fixed effect regression model

H0: sigma(i)^2 = sigma^2 for all i

$\operatorname{chi} 2(54)=9.2 \mathrm{e}+05$

Prob $>$ chi $2=0.0000$ 


\section{List of Figures}

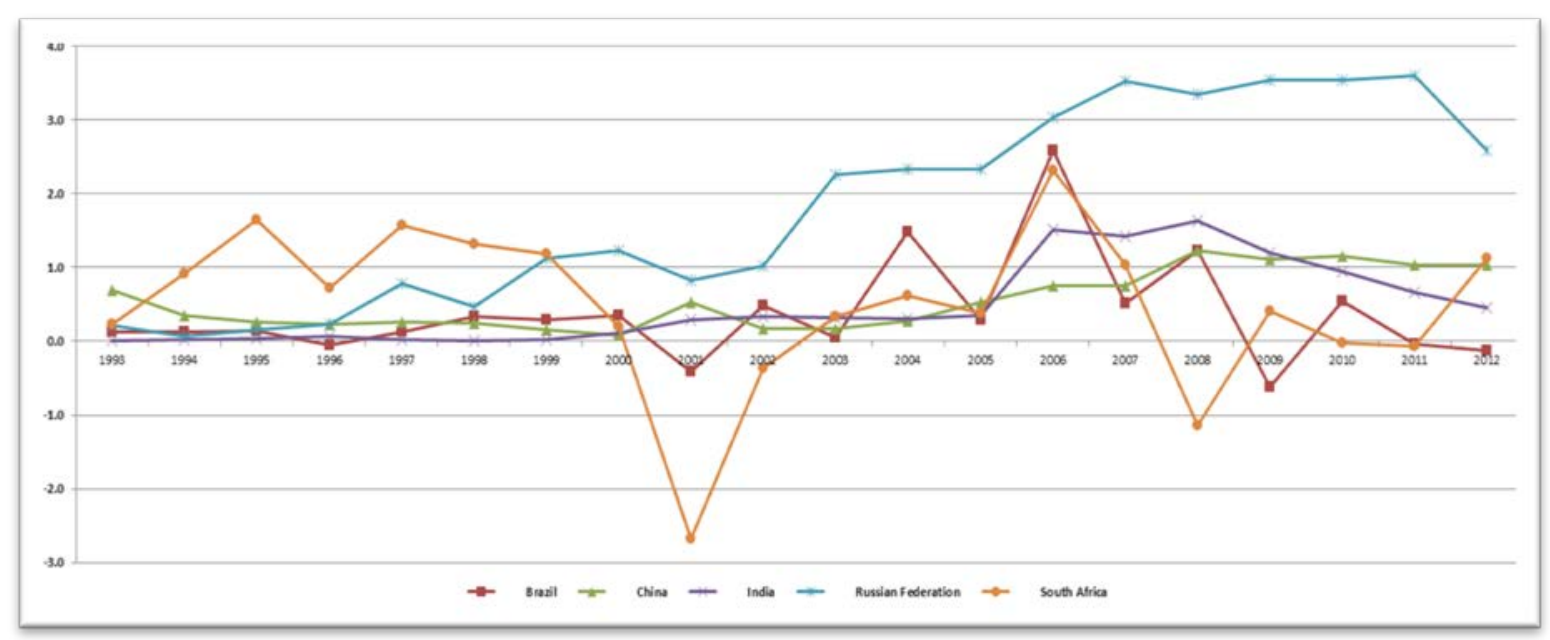

Figure 1: $\quad$ BRICS OFDI flows \% of GDP, 1993-2012

Source: UNCTAD, 2013

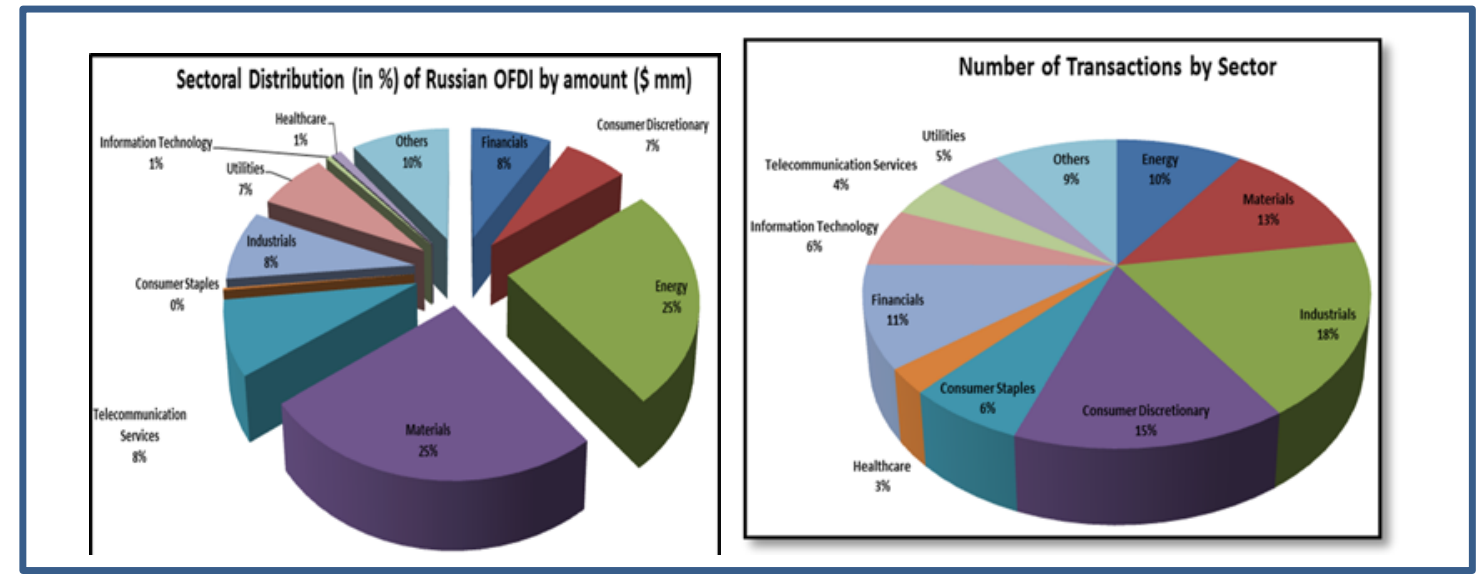

Figure 2: $\quad$ Sectoral Distribution of Russian OFDI

Source: S \& P Capital (2013) 